\title{
Monitoring the Changes of Some Physical, Chemical, Microbial and Enzymatic Parameters during Composting of three Garden Wastes
}

\author{
A. I. Khalil ${ }^{1 *}$, M. N. Ahmed ${ }^{1}$ and H. H. Badry ${ }^{2}$
}

\begin{abstract}
The present study aimed to evaluate the composting (during 25 days) of three garden wastes through the changes in its physical, chemical, microbial and enzymatic parameters by using the bioreactor method. The used wastes were grass clippings and fallen leaves of Jambul trees, Eucalyptus trees and Ficus trees. The obtained results revealed that the physical changes such as temperature reached the maximum value after 10 days and then gradually decreased by the end of composting, while that of ouder and colour showed exhibited clear changes. The values of the chemical parameters including: ash content, total nitrogen (TN), and cation exchange capacity (CEC) were increased by the end of composting, while organic matter $(\mathrm{OM})$, organic carbon (OC) and carbon: nitrogen ratio ( $\mathrm{C} / \mathrm{N}$ ratio) were decreased. The decrease in $\mathrm{pH}$ was recorded after 10 days and then gradually increased and reached the maximum value (from 5.63, 5.00 and 5.89 to $6.72,6.76$ and 7.07 for Jambul, Eucalyptus and Ficus, respectively) by the end of composting. Electrical conductivity (EC) increased during the first ten days and then gradually decreased by proceeding the composting. Both mesophilic bacteria and fungi gradually decreased with time, whereas the thermophilic ones gradually increased and reached the maximum after 10 days and then gradually decreased with time and disappeared by the end of composting. The activity of $\alpha$-amylase increased and reached the maximum value $(0.02,0.02$ and $0.03 \mu \mathrm{mol} / \mathrm{ml} / \mathrm{min}$ for the three garden wastes, respectively) after 5 days and then decreased gradually by the end of composting, while the activity of Carboxymethyl cellulase (CMC ase) increased and reached the maximum value $(0.04 \mu \mathrm{mol} / \mathrm{ml} / \mathrm{min})$ for the three garden wastes from starting composting process after 5 days and then decreased gradually by the end of composting. Finally, the activity of xylanase increased and reached the maximum value $(0.23,0.23$ and 0.24 $\mu \mathrm{mol} / \mathrm{ml} / \mathrm{min}$ ) for Jambul, Eucalyptus and Ficus garden wastes, respectively, after 10 days and then decreased gradually by the end of composting.
\end{abstract}

Key words: Composting, garden wastes, total nitrogen, organic carbon, enzymes activities.

\section{INTRODUCTION}

Garden waste consists of different organic materials, such as grasses, hedges and tree cuttings, small branches, leaves and wood debris, in addition to some inorganic materials, such as plastic bags, soil and stones. It is heterogeneous, low density component resulting from maintenance of private and public gardens. There are many factors that can affect the composition and properties of garden waste including housing, and waste management strategies, urbanization and climate (Boldrin, 2009). Garden waste is usually burned or deposited with solid municipal wastes. In addition to the harmful effects of burning on the environment, it is economically considered a loss. The emission of toxic gases to the air and hindering the soil microbial activities are among the harmful effects of burning. The accumulation of large quantities of this biomass over a long period of time is a main cause of environmental deterioration, in addition, it leads to potential losses in a material that can be processed into food, feed, and fuel (Bisaria, 1991).

There are increasing amounts of organic wastes, meanwhile, organic matter is continuously lost from the soils due to climatic conditions and intensive farming systems (Massiani and Domeizel, 1996). Nonetheless, it is not recommended to add the untreated organic wastes directly to the soil, to avoid any undesirable impacts (Bass et al., 1992). On the other hand, organic wastes can undergo appropriate biological treatments and then recycled into useful organic matter that can be of great interest to countries suffering from soil degradation (Hassen et al., 1998).

Compositing is one of the proposed alternatives to the disposal of organic wastes, because of its low costs and less impact on the environment (Bustamante et al., 2008; Lu et al., 2008 and Kalib et al., 2018), in addition to its contribution to improve soil fertility (Weber et al., 2007 and Suvendu et al. 2017), and the possibility of its use as growing media in horticulture (Pérez-Murcia $e t$ al., 2005 and Nazim, 2019). Compost is reported to

DOI: 10.21608/asejaiqjsae.2021.160006

${ }^{1}$ Department of Environmental Studies, Institute of Graduate Studies and Research, University of Alexandria, Alexandria, Egypt.

${ }^{2}$ Department of Soil and Water Sciences, Faculty of Agriculture,

University of Alexandria, Alexandria, Egypt.

*Corresponding Author: H. H. Badry, Department of Soil and Water Sciences,

Faculty of Agriculture, University of Alexandria, Egypt.

E-mail: halabadry811@yahoo.com, Tel: +201110331741

Received February 19, 2021, Accepted March 30, 2021 
improve soil biophysical properties and organic matter content, thus, supplying the plants with essential nutrients, which will be reflected on higher yields (Reddy et al., 2005).

Compositing is done through a biological oxidative decomposition of the organic components in the collected wastes. This process usually takes place under controlled conditions, in which the aerobic microorganisms can grow and develop and biodegrade the organic components into a useful final product that can be stored and later used without any harmful effects to the environment (Adhikari et al., 2008). In addition to reduction of the waste's volume, thus occupying less space, compositing destroys the pathogens and transforms nitrogen from the unstable ammonia to other stable organic forms (Zhu, 2007; Lin, 2008). In the composting process, microorganisms and their enzymes play a crucial role in the biological and biochemical conversion of the compost components (Guo et al., 2012). The microorganism's activity, during compositing, transforms the organic matter into a humus-rich product (Vargas-García et al., 2010).

The quality of the end products is mainly dependent on the compositing process, which is considered a successful strategy for sustainable recycling organic waste (Mondini et al., 2004). Most of the compositing research relied on the physico-chemical parameters as an indicator to the success of the process and quality of the end product (Said-Pullicino et al., 2007; Albrecht et al., 2008). However, recently, microbiological and biochemical parameters started to gain more attention as valid indicators for the composting process (Raut et al., 2008; Vargas-García et al., 2010; Liu et al., 2011)
The aim of the current study, therefor, was to evaluate and optimize the composting of garden wastes through tracking and quantifying the changes in their physical, chemical, microbial and enzymatic parameters using a small-scale bioreactor.

\section{MATERIAL AND METHODS}

\section{Garden Wastes:}

Three garden wastes were collected from three different locations at Alexandria Governorate, Egypt: (1) grass clippings and fallen leaves of Jambul trees (Jambul) from water falls area, (2) grass clippings and fallen leaves of Eucalyptus trees (Eucalyptus) from El Hadeed Wa El-Solb garden and (3) grass clippings and fallen leaves of Ficus trees (Ficus) from El- Montaza gardens. These collected garden wastes were cut into small pieces $(0.5-3 \mathrm{~cm})$, air- dried for two weeks.

Preparation of garden wastes for composting: This treatment included wetting the wastes by tap water and also by solution of $0.1 \mathrm{M}\left(\mathrm{NH}_{4}\right)_{2} \mathrm{SO}_{4}$. Rewetting was carried out several times in order to maintain $\mathrm{C} / \mathrm{N}$ ratio of about 30/1 with moisture content of $60 \%$.

Composting system (bioreactor): A static composting unit was designed and used (Fig 1). The bioreactor has cylindrical shape (55 L capacity) and it is made of a plastic container and thermal resistant material (galvanized stainless steel) from inside. It is surrounded with $2 \mathrm{~cm}$ insulator material to maintain minimum heat loss. A constant air flow $(10 \mathrm{~L} / \mathrm{min})$ was applied, from a compressor, into the bottom of the bioreactor for $5 \mathrm{~min}$. every day. In addition, two thermometers were inserted at the bioreactor center for temperature measurement.

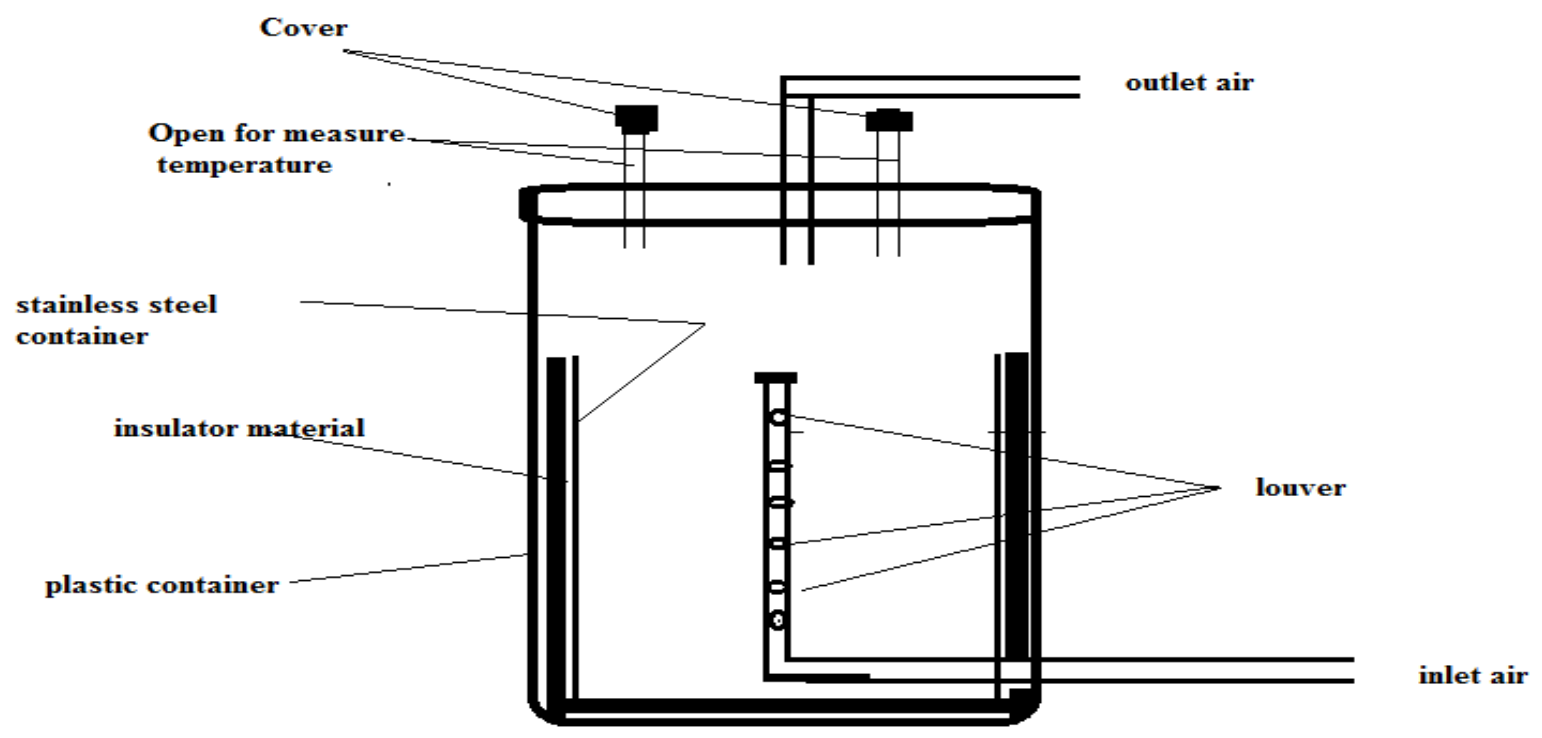

Fig. 1. Schematic diagram of the laboratory composting system (bioreactor) 


\section{Composting Material:}

The garden waste of the adjusted $\mathrm{C} / \mathrm{N}$ ration $(\sim$ $30 / 1$ ) with $60 \%$ moisture content was transfered into the bioreactor which filled up to $80 \%$ of its total volume $\left(0.03 \mathrm{~m}^{3}\right)$. Air inflow was intered the bioreactor during the composting period. Afterwards, the compost from the bioreactor was pooled and transferred to a container for maturation (10 days). During the composting process, some physical, chemical, microbial and enzymatic parameters were monitored. The period of composting was 25 days.

\section{Sampling:}

Three samples $(10.0 \mathrm{~g})$ were taken at random from different locations of the bioreactor. The formed composite sample was then transferred, to the laboratory aseptically in closed bag under cooling for analysis. The compost sampling was carried out every five days.

\section{Analysis:}

Physical analysis: The following measurements were carried out,

(i) Temperature was measured by the thermometer inserted inside the compost mixture in the bioreactor (Alkoaik et al., 2011; Khalil et al., 2014 b)

(ii) The colour was assessed by visual observation, while the odour was through olfactory judgment (Khalil 1996; Pan and Sen, 2013).

(iii) Water holding capacity WHC: Wet compost sample of initial moisture content (Wi) was placed in a beaker, soaked in water for 1-2 days, and the excess water was drained through Whatman filter paper No.2. The weight of the saturated sample was measured (Ws) and the WHC was calculated (Ahn et al., 2008) as follows:

$\mathrm{WHC}(\%)=\left(\mathrm{W}_{\mathrm{s}}-\mathrm{W}_{\mathrm{i}}\right)+\mathrm{MC} \mathrm{X} \mathrm{Wi} /(1-\mathrm{MC}) \mathrm{X} \mathrm{Wi}$

Where; MC is the initial moisture content of the sample, and WHC is in $\mathrm{g}$ water/g dry material.

(iv) Bulk density: Approximate known volume container was filled with compost sample. This sample was slightly compacted to ensure absence of large void spaces. The bulk density $\left(\mathrm{g} / \mathrm{cm}^{3}\right)$ was calculated by dividing the weight of sample $(\mathrm{g})$ by its volume $\left(\mathrm{cm}^{3}\right)$ according to Khater (2015)

Chemical analysis: The following measurements were carried out,

(i) Ash content $(\mathrm{X})$ was determined (5 g) after drying the fresh sample at $105^{\circ} \mathrm{C}$ to $24 \mathrm{hrs}$ and then ashing at $550^{\circ} \mathrm{C}$ in a muffle furnace for $5 \mathrm{hrs}$ (WHO, 1978; Cabanas-Vargas et al., 2005; Jindo et al., 2012)

(ii) Organic matter (OM) and organic carbon (OC) were estimated as follows:

$\mathrm{OM}(\%)=100-\mathrm{X}(\%)$
$\mathrm{OC}(\%)=\mathrm{OM}(\%) / 1.8$

(WHO, 1978; Faure and Deschamps, 1990; Abdullah and Chin, 2010)

(iii) Total nitrogen (TN) was determined by Kjeldahl method as described by WHO (1978), Half gram oven-dried $\left(65{ }^{\circ} \mathrm{C} / 24 \mathrm{hrs}\right)$ compost sample was digested in $10 \mathrm{ml}$ conc. $\mathrm{H}_{2} \mathrm{SO}_{4}$ and $1.1 \mathrm{~g}$ catalyst (1: 2: 74 parts of selenium: $\mathrm{CuSO}_{4} .5 \mathrm{H}_{2} \mathrm{O}: \mathrm{K}_{2} \mathrm{SO}_{4}$ ). After distillation, the produced ammonia was received in Boric acid indicator solution and titration with $0.05 \mathrm{NH}_{2} \mathrm{SO}_{4}$ solution. TN was calculated as follows:

$\mathrm{TN}(\%)=\mathrm{N} \times \mathrm{V} \times 0.014$ / weight of sample, $\mathrm{g}$

(iv) The $\mathrm{pH}$ was determined by shaking $5.0 \mathrm{~g}$ compost sample with $50 \mathrm{ml}$ distilled water for $30 \mathrm{~min}$. and the $\mathrm{pH}$ was measured in the suspension using $\mathrm{pH}$ metes (Moldes et al., 2007).

(v) The electrical conductivity (EC) was measured by shaking $5.0 \mathrm{~g}$ compost sample with $50.0 \mathrm{ml}$ distilled water for $30 \mathrm{~min}$., filtered through Whatman filter paper No. 42 and the EC was measured by conductivity meter (Petric and Selimbasic, 2008; Madan et al. 2012)

(vi) Cation exchange capacity (CEC) was determined according to the method described by (Bache, 1976).

Microbiological analysis: One gram compost sample was suspended in $99.0 \mathrm{ml}$ sterile saline solution $(9 \mathrm{~g}$ $\mathrm{NaCl} / \mathrm{L}$ ) and shaken for $30 \mathrm{~min}$. Bacteria and fungi (both mesophilic and thermophilic) were isolated as described by Nakasaki et al. (1992). Nutrient ager (NA) and potatos dextrose agar (PDA) media were used for bacteria and fungi, respectively. Incubation temperature of $30{ }^{\circ} \mathrm{C}$ was used for isolation of mesophiles and $50 \mathrm{C}^{\circ}$ was used for isolation of thermophiles. Incubation time was 3 days for mesophylic and thermophilic bacteria, and 5 days for mesophilic and thermophilic fungi. The average number of microorganisms isolated on three plates was expressed as colony-forming units (CFU) per wet weight of compost (Khalil et al., 2014 a and 2014 b)

Enzymatic analysis: Compost extract was obtained by transferring $10.0 \mathrm{~g}$ fresh compost to a conical flask containing $50.0 \mathrm{ml}$ acetate butter solution $(0.1 \mathrm{M}$, pH 5.0), shaken at $150 \mathrm{rpm}$ for $30 \mathrm{~min}$, then filtered through a cheese cloth. Ten $\mathrm{ml}$ from the filtrate were centrifuged at $5000 \mathrm{rpm}$ for $15 \mathrm{~min}$, and the supernatant was used for the determination of enzymes activities (Khalil et al., 2001 and 2014 a)

The activities of $\alpha$-amylase, carboxymethyl cellulase (CMC) and xylanase were determined by measuring the reducing sugar liberated from starch, CMC and beechwood xylan, respectively by dinitrosalicylic acid 
(DNSA) method of Miller (1959). The absorbance of the resultant colour was measured at $540 \mathrm{~nm}$ using spectrophotometer (Thermo Scientific Co, USA). All assays were done in 4 replicates. One unit (U) of enzyme activity was defined as the amount of enzyme that release $1 \mu \mathrm{mol}$ glucose from the starch and CMC substance or xylose from the beechwood xylan substrate per min under assay conditions stated (Ja'afaru, 2013; Fusawat and Rakariyatham, 2014).

Statistical Analysis:The obtained data were statistically analyzed for variance (ANOVA) using IBM SPSS software package version 20.0. The values were compared for the significance difference using least significant difference (LSD) at $\mathrm{p} \geq 0.05$ (Kikpatrick and feeney, 2013)

\section{RESULTS AND DISCUSSION}

This study evaluates the efficiency of composting process of three sources of garden wastes through monitoring the changes in their physical, chemical, microbial and enzymatic parameters.

\section{Physical Changes:}

Temperature: Figure (2) showed gradual increases of the temperature from 33.2 to 40.5 , from 37.5 to 55.6 and from 33.2 to $59.3 \mathrm{C}^{\circ}$ for Jambul, Eucalyptus and Ficus tree, respectively during the incubation time 0 and 10 days. The highest temperature $\left(59.3 \mathrm{C}^{\circ}\right)$ was that of Ficus tree garden waste and the lowest $\left(40.5 \mathrm{C}^{\circ}\right)$ was that of Jambul tree garden waste, while the moderate $\left(55.6 \mathrm{C}^{\circ}\right)$ was that of Eucalyptus tree garden waste at the $10^{\text {th }}$ day of composting (Fig 2). Afterwards, the temperature decreased gradually to $30.8,29.2$ and $28 \mathrm{C}^{\circ}$ at the 25 day of incubation for these three garden wastes, respectively. The increase of temperature during the first 10 days of composting may be due to the abundant and activity of indigenous microorganisms in the row compost materials and also to the suitability of composting conditions for stimulating microbial and enzymatic activities. On the other hand, the decrease of temperature may be attributed to the decrease of microbial and enzymatic activities because most of the easily degradable organic compounds have been metabolized according to Khalil et al. (2014 a and 2014 b). This has been also confirmed by Zakarya et al. (2015). It is clear from the present study that the compost temperature did not exceed $60 \mathrm{C}^{\circ}$. Similar findings have been reported by Fogarty and Touvinen (1991) who declared that the temperature of the composting process should not exceed $60 \mathrm{C}^{\circ}$ in order to avoid thermal inactivation of the desired microbial community necessary for efficient degradation of organic wastes.

Odour: The observed results indicated that the unpleasant odour of the composting materials had decreased with time. By the end of composting (25 days) the compost was nearly odourless. Similar observations were found by Khalil et al. (2014 a and b).

Colour: It has been noticed that during composting process there was a gradual darkening of the composted materials which gave an indication of maturity process. The obtained compost was nearly homogenous with a dark brown colour which agrees with those reported by Gotass (1956) and Diaz et al. (1993) who mentioned that the matured compost should be greyish- black or brownish-black in colour.

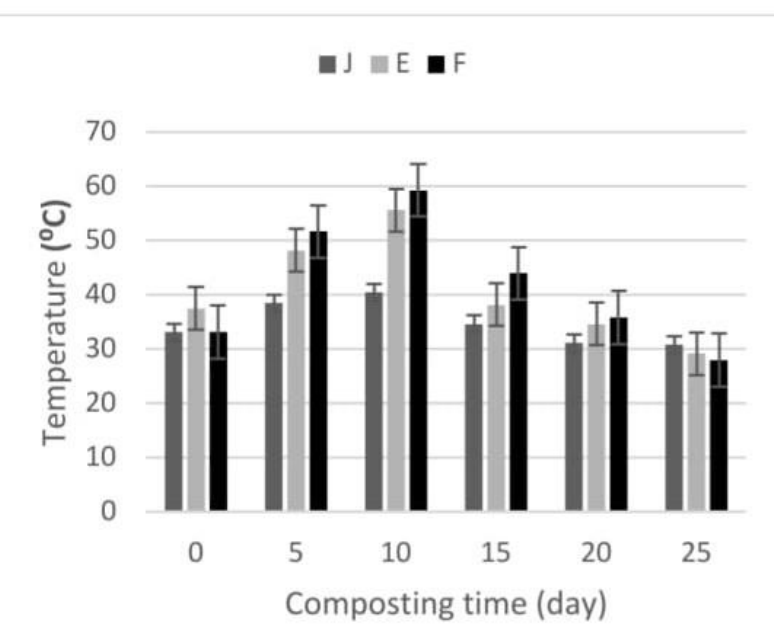

Fig.2. Changes in temperature during the composting of garden wastes of Jambul (J), Eucalyptus (E) and Ficus (F) trees. Values are means of six replicates \pm standard errors

\section{Chemical Changes:}

Ash content: Figure (3) showed that ash content in the three garden wastes gradually increased by proceeding composting time. It increased from 14.50 to 36.47 , from 14.58 to 36.81 and from 14.40 to $37.08 \%$ by the end of composting process (25 days) for Jambul, Eucalyptus and Ficus tree waste, respectively. The results revealed that there were significant differences between the ash contents with time. Similar results have been reported by Khalil (1996); Beheary (2000); Shaheen (2007); Khalil (2011, 2014 a, 2014 b). It has been reported that the increase of ash content due to composting is a result of a decrease in OM content due to mineralization and humification (Auldry et al., 2009). The highest rate of change in ash percentage was recorded during the first 5 days of composting with values of $+0.23,+1.83$ and $+2.31 \%$ per day in the case of Jambul, Eucalyptus and Ficus garden waste, respectively. However, there were lower values of rate of change in ash percentage during the last 5 days (20- 25 day) of composting with values 
of $+0.024,+0.110$ and $+0.038 \%$ per day for the three garden wastes, respectively.

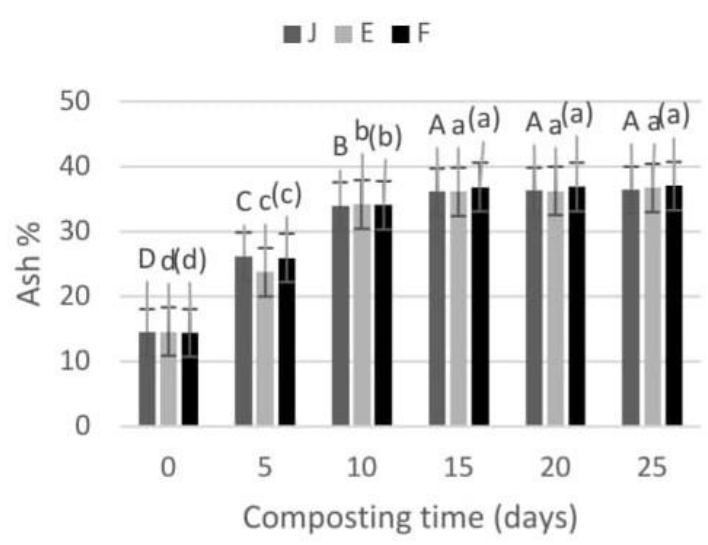

Fig. 3. Changes in ash content (\%) during the composting of garden wastes of Jambul (J), Eucalyptus (E) and Ficus (F). Values are means of four replicates \pm standard errors

(Bars marked with the same capital letter indicate no significant deference for Jambul leaves, small letter is for Eucalyptus leaves, small letter between bracket's is for Ficus leaves)

Organic matter (OM): Figure 4 showed that $\mathrm{OM}$ content gradually decreased by time since it decreased from 85.50 to 63.53 , from 85.43 to 63.19 and from 85.60 to $62.92 \%$ by the end of composting process ( 25 days) for Jambul, Eucalyptus and Ficus garden waste, respectively. The obtained results agree with those found by Khalil (1996); Beheary (2000); Shaheen (2007); Khalil et al. (2011, 2014 a, 2014 b). The reduction in $\mathrm{OM}$ content is due to decomposition and use of $\mathrm{OM}$ as a source of energy by microorganisms (Gajalakshima and Abbasia, 2008; Kalamdhad and Kamsi, 2009). It was stated that the amount of OM degraded was higher in the first week of composting than in the rest time of composting process which is attributed to high microbial activities (Saludes et al., 2008). The highest degradation of OM, due to composting, occurred in the first 5 days as indicating by the values of rate of change which were $-2.34,1.84$ and 2.31 percent of $\mathrm{OM} /$ day while these values were $0.024,-0.112$ and -0.038 percent $\mathrm{OM} /$ day during the last 5 days (20-25 day) in the case of Jambul, Eucalyptus and Ficus garden waste, respectively.

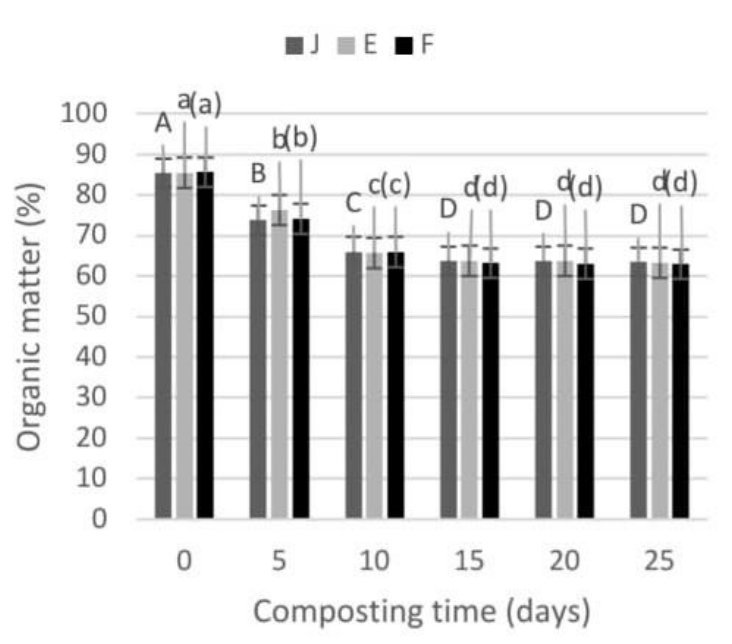

Fig.4. Changes in organic matter (OM) during the composting of garden wastes in case of Jambul $(\mathrm{J})$, Eucalyptus (E) and Ficus (F). Values are means of four replicates \pm standard errors

(Bars marked with the same capital letter indicate no significant deference for Jambul leaves, small letter is for Eucalyptus leaves, small letter between bracket's is for Ficus leaves)

Organic carbon (OC): Figure 5 showed that the amount of OC in the three garden wastes gradually decreased by proceeding composting time. It decreased from 47.48 to 35.27 , from 47.45 to 35.10 and from 47.55 to $34.95 \%$ by the end of composting process (at 25 days) for Jambul, Eucalyptus and Ficus garden waste, respectively. There were also significant differences in the amounts of OC between time periods. The values of rate of change in OC percentage per day in the first 5 days were $-1.30,1.02$ and 1.28 and in the last 5 days (20-25 day) were $-0.016,-0.062$ and 0.022 in the case of Jambul, Eucalyptus and Ficus garden waste, respectively. These data indicate lower degradation rate of $\mathrm{OM}$ at the end of composting process (20-25 day) as compared with those occurred during the start (0-5 days) of composting process. These results agree with those found by Khalil (1996), Shaheen (2007), Khalil et al. (2011, 2014 a, 2014 b) and Awasthi et al. (2015). The reduction in the amount of $\mathrm{OC}$ is the result of evolution of $\mathrm{C}$ as $\mathrm{CO}_{2}$ and assimilation in microbial biomass as suggested by Cabrera et al. (2005). It was also reported that the rate of OC decomposition is strongly related to the microbial activity in the compost (Zmora-Nahum et al., 2005). 


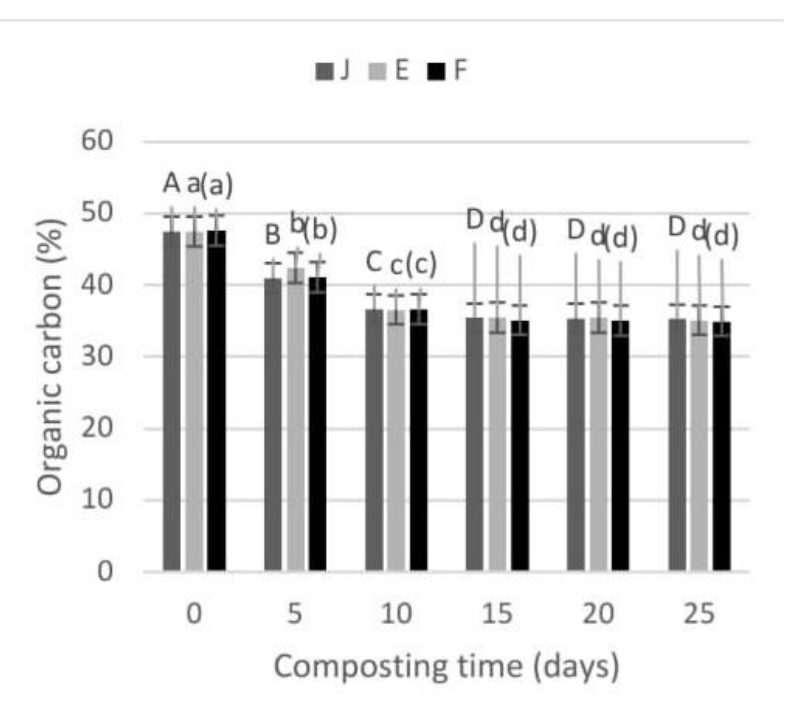

Fig. 5. Changes in organic carbon $(\mathrm{OC})$ during the composting of garden wastes of Jambul $(\mathbf{J})$, Eucalyptus (E) and Ficus (F). Values are means of four replicates \pm standard errors

(Bars marked with the same capital letter indicate no significant deference for Jambul leaves, small letter is for Eucalyptus leaves, small letter between bracket's is for Ficus leaves)

Total nitrogen (TN): Figure 6 showed that the amount of TN in the three garden wastes gradually increased by increasing composting time. It increased from 1.65 to 1.80, from 1.66 to $1.78 \%$ for Eucalyptus and Ficus garden wastes, respectively, up to the end of composting process. However, it decrease from 1.7 to $1.5 \%$ for Jambul garden waste up to the end of composting. It is also recorded that there were significant difference in the amount of TN of the three garden wastes during each time period. Very close results were obtained by Khalil (1996), Shaheen (2007), Kalamdhad et al. (2009) and Jusoh et al., (2013). The decrease of TN in Jambul garden waste compost may be attributed to ammonia volatilization in the initial stage of composting. This could be due to the loss of $\mathrm{N}$ in the form of ammonia which depends on type of material and $\mathrm{C} / \mathrm{N}$ ratio (Goyal et al., 2005 and Khalib et al., 2018). The values of rate of change of TN percentage per day were +0.006 and + 0.008 in the case of Eucalyptus and Ficus garden wastes, respectively in first 5 days of composting and were +0.008 and 0.002 in the last 5 days (20-25days) of composting, respectively. However, Jambul garden wastes behaved appositively and the values of rate of change in TN percentage per day were -0.014 and 0.000 , in the first 5 days and the last 5 days of composting, respectively.

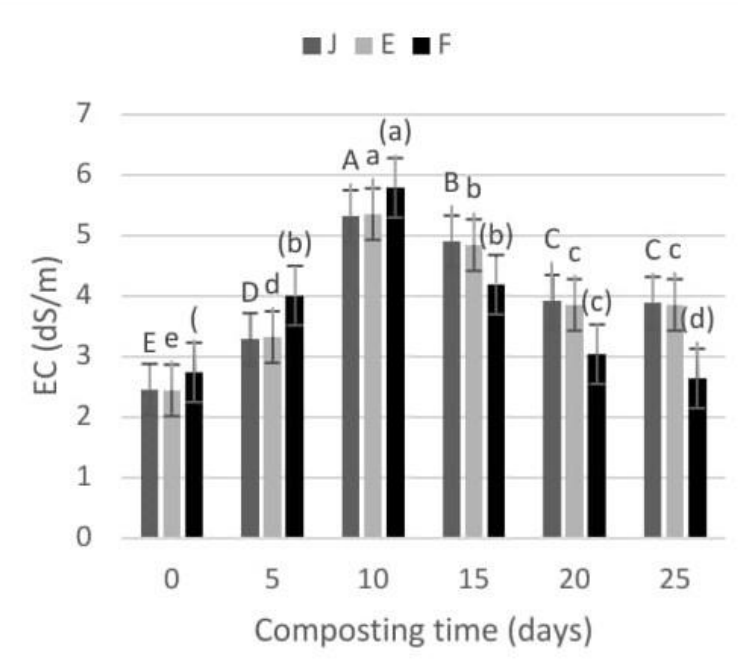

Fig. 6. Changes in total nitrogen (TN) during the composting of garden wastes of Jambul (J), Eucalyptus (E) and Ficus (F). Values are means of four replicates \pm standard errors

(Bars marked with the same capital letter indicate no significant deference for Jambul leaves, small letter is for Eucalyptus leaves, small letter between bracket's is for Ficus leaves)

Carbon: Nitrogen ratio (C/N ratio): Figure (7) indicated that $\mathrm{C} / \mathrm{N}$ ratio gradually decreased by time of composting. It decreased from 28.01 to 23.55 , from 28.85 to 19.52 and from 28.64 to 19.63 by the end of composting process (25 days) in the cases of Jambul, Eucalyptus and Ficus garden wastes, respectively. There were also significant differences in the levels of $\mathrm{C} / \mathrm{N}$ ratio between composting time of the three garden wastes composts. These results agree with those reported by Khalil (1996); Shaheen (2007); Beheery (2000) Alkoaik et al. (2011); and Khalil et al. (2014 a, $2014 \mathrm{~b}$ ). It have been reported that the decrease of $\mathrm{C} / \mathrm{N}$ ratio may be due to the use of $\mathrm{OC}$ as a source of energy by microorganisms, and to utilization of $\mathrm{N}$ for building cell structure of deferent groups of microorganisms (Adhikari et al. 2009; Yadav and Garg, 2009; Yadav et al., 2011 and Jusoh et al., 2013). In addition, the loss of $\mathrm{C}$ as $\mathrm{CO}_{2}$ decreased $\mathrm{C} / \mathrm{N}$ ratio (Goyal et al., 2005).

pH: Figure (8) showed gradual decrease of $\mathrm{pH}$ of the three garden wastes as a result of composting. It decreased from $6.92,6.87$ and 6.47 of the initial state of the three garden waste to $5.63,5.00$ and 5.89 after 10 days composting in the case of Jambul, Eucalyptus and Ficus garden waste, respectively. The $\mathrm{pH}$ then gradually increased to 6.72, 6.76 and 7.07 for the three garden wastes respectively at the end of composting ( 25 days). 


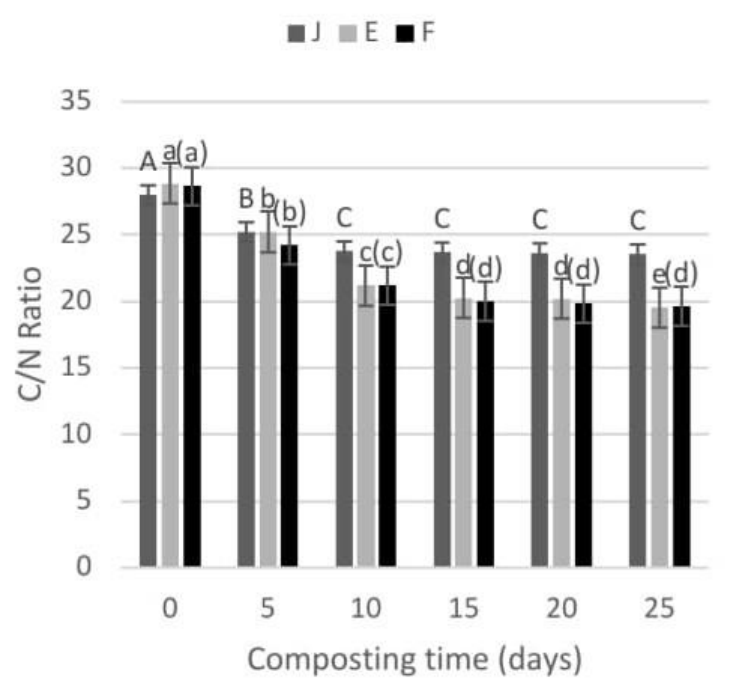

Fig. 7. Changes in $\mathrm{C} / \mathrm{N}$ ratio during the composting of garden wastes of Jambul (J), Eucalyptus (E) and Ficus (F). Values are means of four replicates \pm standard errors

(Bars marked with the same capital letter indicate no significant deference for Jambul leaves, small letter is for Eucalyptus leaves, small letter between bracket's is for Ficus leaves)

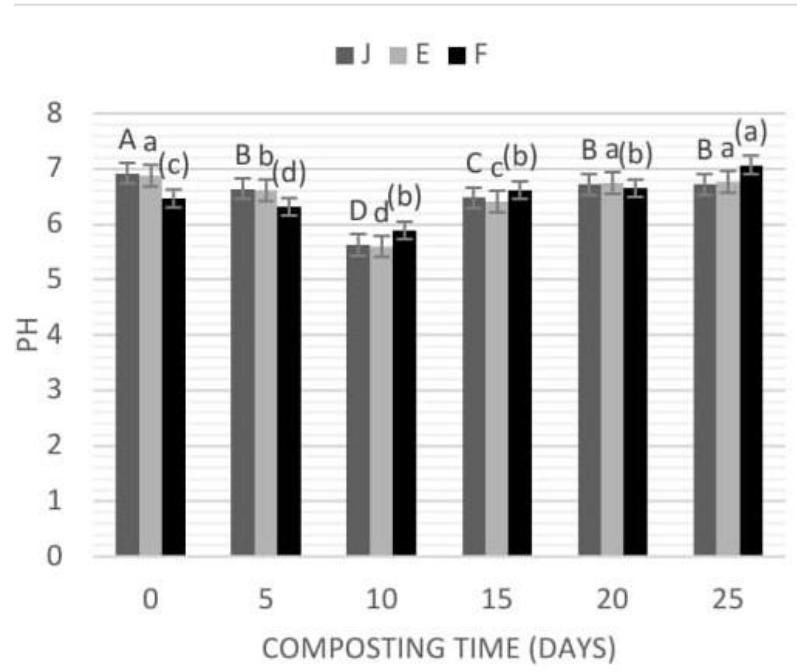

Fig.8. Changes in $\mathrm{pH}$ during the composting of garden wastes of Jambul (J), Eucalyptus (E) and Ficus (F). Values are means of four replicates \pm standard errors

(Bars marked with the same capital letter indicate no significant deference for Jambul leaves, small letter is for Eucalyptus leaves, small letter between bracket's is for Ficus leaves)
There were significant difference between the $\mathrm{pH}$ values with each time period. The decrease of $\mathrm{pH}$ values of these three wastes could be attributed the presence of organic acids in garden wastes. This also has been confirmed by Smars et al. (2002) and Adhikari et al. (2009). It has been reported also that the decrease of $\mathrm{pH}$ during composting could be attributed to loss of ammonia and accumulation of organic acids (Chukwujindu et al., 2006; Banegas et al., 2007; Kayikcioglu; Okur, 2011 and Khalib et al., 2018).

Electrical conductivity (EC): Figure (9) indicated an increase of EC value from 2.45, 2.44 and $2.73 \mathrm{dS} / \mathrm{m}$ at the $10^{\text {th }}$ day of composting then gradually decreased to $3.88,3.85$ and $2.46 \mathrm{dS} / \mathrm{m}$ at the end of composting (at 25 days) for Jambul, Eucalyptus and Ficus garden wastes, respectively. The results indicated significant differences in EC values with time. The increase of EC could be attributed to increased salts concentrations as a result of mineralization of $\mathrm{OM}$ and production of ammonium, nitrate or nitrite ions which usually occurred in the beginning of composting (first 10 days) as reported by Michel and Reddy (1998), GumezBrandum et al. (2008); Villasenor et al. (2011) and Wang et al. (2016).

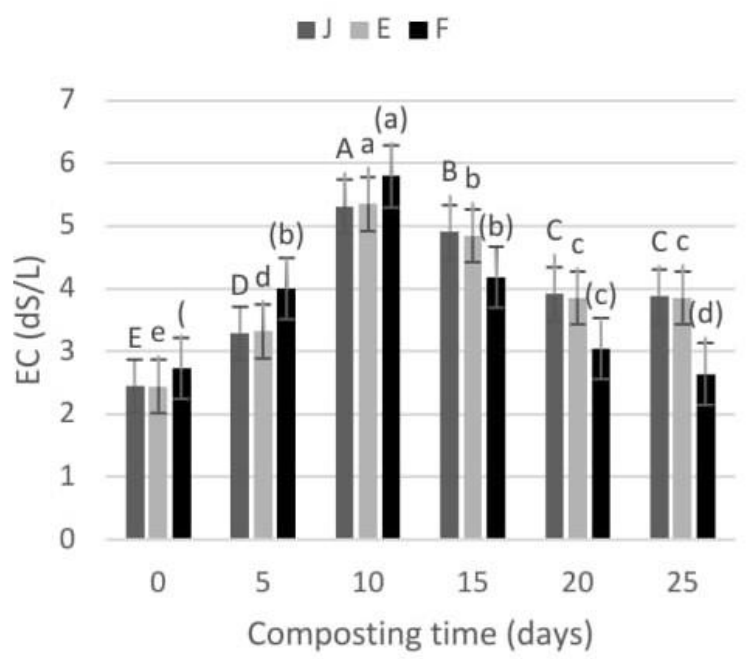

Fig. 9. Changes in electrical conductivity (EC) during the composting of garden wastes of Jambul (J), Eucalyptus (E) and Ficus (F). Values are means of four replicates \pm standard errors

(Bars marked with the same capital letter indicate no significant deference for Jambul leaves, small letter is for Eucalyptus leaves, small letter between bracket's is for Ficus leaves) 
Cation exchange capacity (CEC): The values of CEC of the three garden wastes composts increased from $13.10,13.40$ and $14.15 \mathrm{cmol} / \mathrm{kg}$ for initial garden wastes of Jambul, Eucalyptus and Ficus wastes, respectively with proceeding composting process to $21.20,24.80$ and $23.40 \mathrm{cmol} / \mathrm{kg}$ with the end of composting process (25 days), respectively. These increases have been suggested to be attributed to humification of organic materials and formation of carboxyl and phenolic function groups (Benito et al., 2003; and Saharinen, 1998).

\section{Microbial Changes:}

Mesophilic bacteria: It is clear from Fig. 10 that the number of mesophilic bacteria gradually decreased with proceeding composting process. It decreased from 2.29 $\times 10^{8}, 2.23 \times 10^{8}$ and $2.34 \times 10^{8} \mathrm{cfu} / \mathrm{g}$ wet compost in the initial garden waste of Jambul, Eucalyptus and Ficus, respectively, to $4.16 \times 10^{7}, 3.71 \times 10^{7}$ and $3.89 \times$ $10^{8}$ respectively by the end of composting process (at 25 days). It is clear also from Fig. 10 that there were significant differences between the microbial counts with time. These decreases may be due to high temperature and low moisture content during composting period, as reported by Khalil et al. (2014 a and b). Similar results were found by Chang and Hudson (1967); Khalil et al. (1999); Hassen et al. (2001); Shaheen (2007).

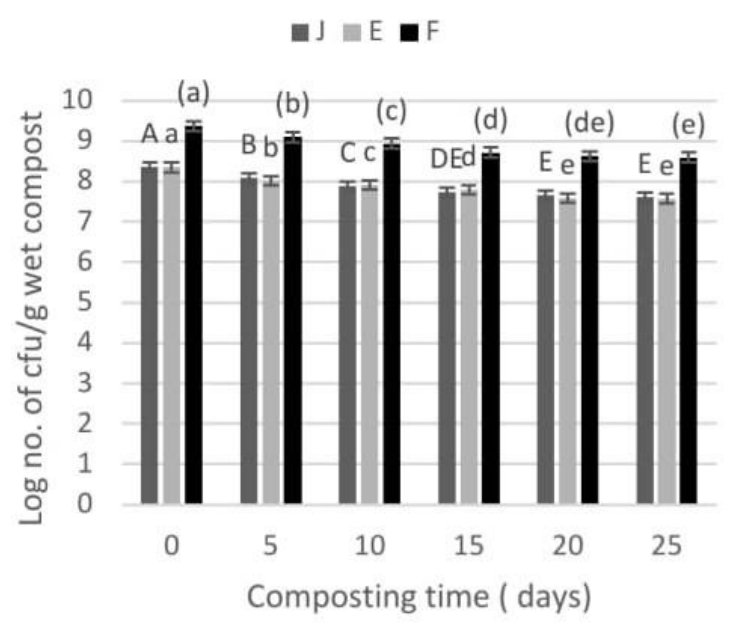

Fig.10. Changes in total counts of mesophilic bacteria during the composting of garden wastes of Jambul (J), Eucalyptus (E) and Ficus (F). Values are means of three replicates \pm standard errors. c.f.u.: colony-forming units

(Bars marked with the same capital letter indicate no significant deference for Jambul leaves, small letter is for Eucalyptus leaves, small letter between bracket's is for Ficus leaves)
Thermophilic bacteria: As shown in Fig 11, the number of thermophilic bacteria gradually increased and reached the maximum $\left(1.17 \times 10^{8}, 1.25 \times 10^{8}\right.$, and 1.34 $\times 10^{9} \mathrm{cfu} / \mathrm{g}$ wet compost) after 10 days of composting in case of Jambul, Eucalyptus and Ficus leaves wastes, respectively. These bacteria gradually decreased with proceeding composting and disappeared by the end $(25$ days). Chang and Hudsm (1967) found that the number of thermophilic bacteria had increased during the first 2 days of composting and then gradually decreased at the end of composting. The obtained results (Fig 11) indicated significant differences between numbers of thermophilic bacteria with time. The decrease in number of thermophilic bacteria could be due to the low temperatures as reported by Khalil et al. (2014 a, 2014 b). Similar results were found by Khalil et al., (2001); Shaheen (2007). Jimenez and Garcia (1989) stated that the number of thermophilic bacteria had decreased in the last phases of composting as the product reaches maturity, and this can be indicative to the state of compost maturity. It has been also reported that during the thermophilic phases; most of the biological activity is attributed to spore forming thermophiles, and high temperatures accelerate the breakdown of proteins, fats, and complex carbohydrates such as cellulose and hemicellulose (Fujio and Kume, 1991; Elango et al., 2008).

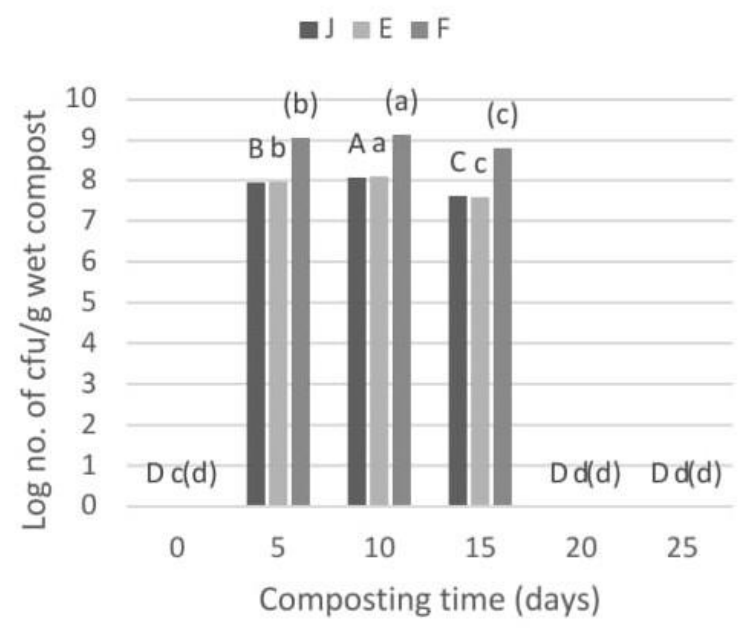

Fig. 11. Changes in total counts of thermophilic bacteria during the composting of garden wastes of Jambul (J), Eucalyptus (E) and Ficus (F). Values are means of three replicates \pm standard errors. c.f.u.: colony-forming units

(Bars marked with the same capital letter indicate no significant deference for Jambul leaves, small letter is for Eucalyptus leaves, small letter between bracket's is for Ficus leaves) 
As these compounds are exhausted, the compost temperatures decreases and the mesophilic microorganisms once again take part for the final phase of curing or maturation of the remaining organic matter (Shilev et al., 2006).

Mesophilic fungi: Figure 12 showed that the number of mesophilic fungi gradually decreased with proceeding composting process from $6.76 \times 10^{7}, 7.24 \times 10^{8}$ and $7.07 \times 10^{7} \mathrm{cfu} / \mathrm{g}$ wet compost at zero day to $1.38 \times 10^{6}$, $1.12 \times 10^{7}$ and $1.20 \times 10^{7} \mathrm{cfu} / \mathrm{g}$ wet compost by the end of composting in case of Jambul, Eucalyptus and Ficus leaves wastes, respectively, There were also significant differences between number of mesophilic fungi with time. These decreases in number of mesophilic fungi could be due to the high temperature of the compost as reported by (Khalil et al., 2001; Shaheen 2007; Khalil et al., 2013).

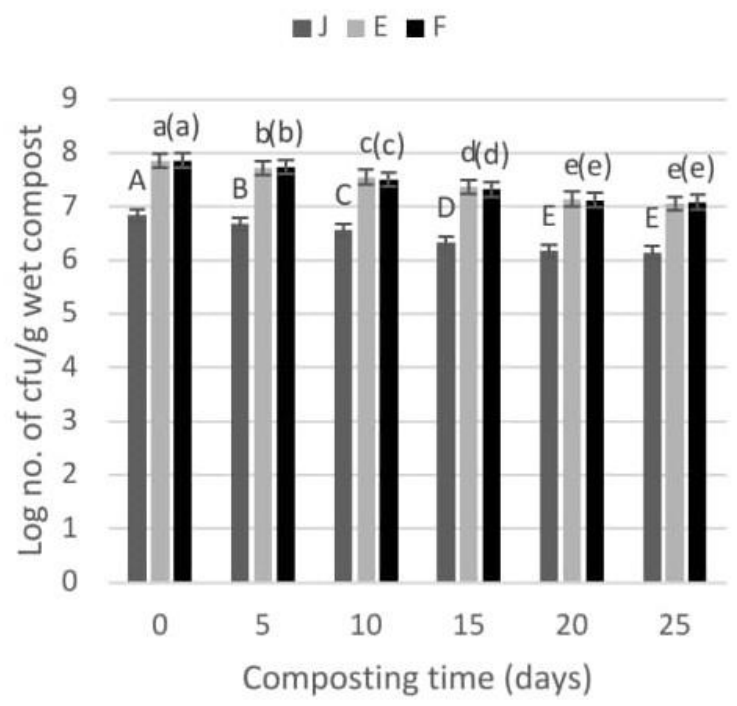

Fig. 12. Changes in total counts of mesophilic fungi during the composting of garden wastes of Jambul (J), Eucalyptus (E) and Ficus (F). Values are means of three replicates \pm standard errors. c.f.u.: colonyforming units

(Bars marked with the same capital letter indicate no significant deference for Jambul leaves, small letter is for Eucalyptus leaves, small letter between bracket's is for Ficus leaves)

Thermophilic fungi: Figure (13) showed gradual increase in the number of thermophilic fungi and then reached the maximum value after 10 days of composting which were $6.45 \times 10^{6}, 6.76 \times 10^{6}$ and 7.76 $\times 10^{7} \mathrm{cfu} / \mathrm{g}$ wet compost of Jambul, Eucalyptus and Ficus garden wastes, respectively. It is then gradually decreased with time and disappeared by the end of composting (Fig 13). There were also significant differences between the fungi numbers with time (Fig 13). The recorded increase in numbers of thermophilic fungi could be due to high temperature maintained during composting as reported by (Khalil et al., 2014 a, b). Similar findings were reported by Shaheen (2007).

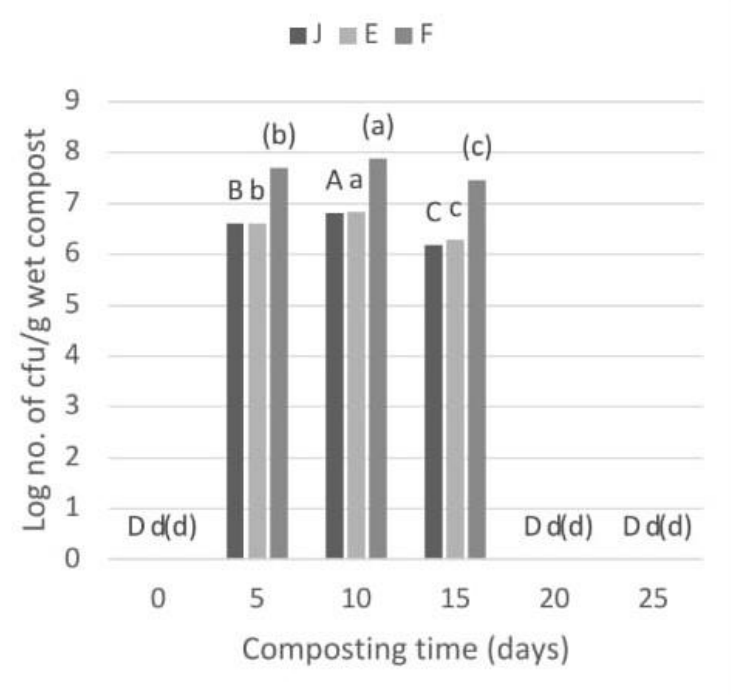

Fig. 13. Changes in total counts of thermophilic fungi during the composting of garden wastes of Jambul (J), Eucalyptus (E) and Ficus (F). Values are means of three replicates \pm standard errors. c.f.u.: colonyforming units

(Bars marked with the same capital letter indicate no significant deference for Jambul leaves, small letter is for Eucalyptus leaves, small letter between bracket's is for Ficus leaves)

Monitoring microbial changes during composting process provides information about the degree of stabilization of organic materials in the studied garden wastes. The results obtained indicated that the most effective microorganisms are mesophilic and thermophilic bacteria. However, the mesophilic fungi has a short time span in the composting process. Bacteria had high ability to grow rapidly and are mostly tolerant to high temperature (Miller, 1992). It is clear from the obtained results that mesophilic bacteria and fungi are responsible for the initial decomposition of organic materials and that the generation heat is responsible for increasing composting temperature (Fogarty and Tuovinen, 1991). It can be observed that the microbial biomass of thermophilic bacteria had decreased in the last phase of composting as the product reaches maturity. Thus, a total count of bacteria throughout the composting period can be the indicative to the state of the compost maturity (Jimenez and 
Garcia, 1989). It is clear, that the gradual decrease in both temperature and in counts of bacteria and fungi towards the end of composting process indicate the depletion of nutrients and that this process is approaching stability, as result less heat is generated in the compost as by reported by Kutsanedzie et al., (2012).

\section{Enzymatic Changes:}

a- Amylase: The obtained results showed that the activity of $\alpha$ - amylase increased as a result of composting of Jambul, Eucalyptus and Ficus garden wastes and reached the maximum significant values $(0.02,0.02$ and $0.03 \mu \mathrm{mol} / \mathrm{ml} / \mathrm{min}$ for the three garden wastes, respectively) at the $5^{\text {th }}$ day of composting. It then gradually decreased and reached zero activity at the $10^{\text {th }}$ days of composting process. The maximum enzyme activity, was reached in the $5^{\text {th }}$ day, which could be attributed to the fast degradation of cellulose and hemicellulose as found by Khalil et al., (2014 a). Several studies reported that the maximum activity of $\alpha$ amylase has been recorded after 7 days of composting (Khalil et al., 1999), after 9 days of composting (Raut $e t$ al., 2008), after 10 days of composting (Khalil et al., 2012; 2013, 2014 a) then had decreased after that. Rout et al. (2008) and Zameer et al. (2010) found that the early degradation of starch may be a result of increasing microbial biomass during the initial phase of composting. The obtained results showed also very low activity of $\alpha$ - amylase in the final stage of composting (15- 25 days).

Carboxymethyl cellulase (CMC ase): Figure 14 showed that the activity of CMC ase had increased and reached the maximum value after 5 days (0.04 $\mu \mathrm{mol} / \mathrm{ml} / \mathrm{min}$ ) for the three garden wastes from starting composting process, then decreased reached the minimum at the $10^{\text {th }}$ day of composting $(0.03$ $\mu \mathrm{mol} / \mathrm{ml} / \mathrm{min}$ ) for the three tree garden wastes. There were also significant differences between enzyme activity with time. However, the studied caried out by Khalil et al. (1999, 2001 and 2012) showed that maximum activity of CMC ase was found after three weeks from composting, while it was during 10-30 days from composting as reported by Khalil et al. (2013), and at 30 days from composting as found by Goyal et al. (2005), and between 30-40 days of composting according to Shaheen (2007) and 40 days as found by Khalil et al. (2014 a), then decreased afterwards.

Xylanase: Figure 15 indicated that the activity of xylanase had increased and reached the maximum values $(0.23,0.23$ and $0.24 \mu \mathrm{mol} / \mathrm{ml} / \mathrm{min})$ for Jambul, Eucalyptus and Ficus garden wastes, respectively at the $10^{\text {th }}$ day of composting and then gradually decreased.

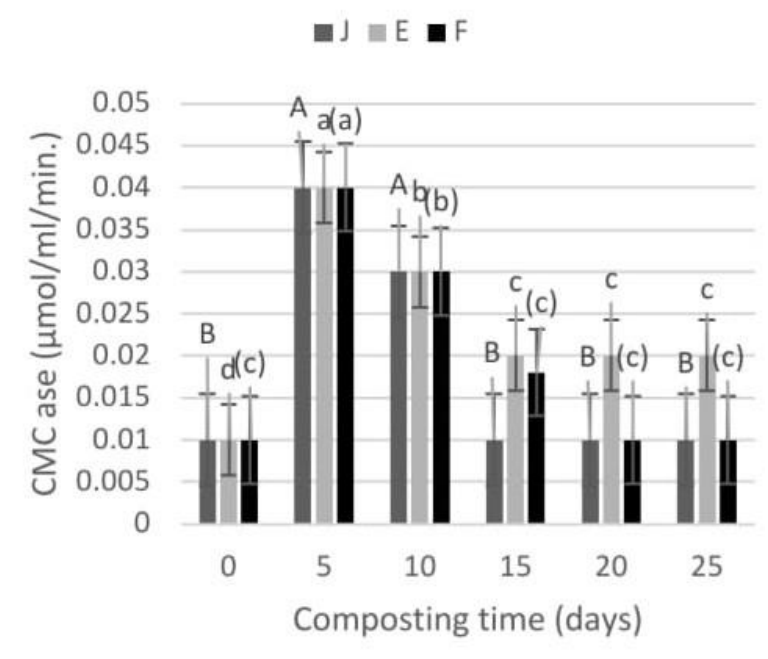

Fig. 14. Changes in CMC ase activity during the composting of garden wastes of Jambul (J), Eucalyptus (E) and Ficus (F). Values are means of four replicates \pm standard errors

(Bars marked with the same capital letter indicate no significant deference for Jambul leaves, small letter is for Eucalyptus leaves, small letter between bracket's is for Ficus leaves)

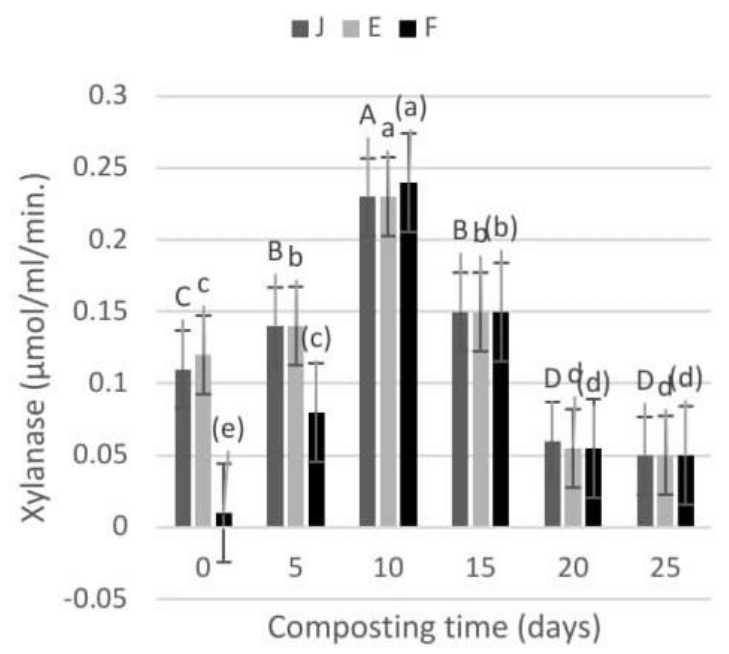

Fig.15. Changes in Xylanase activity during the composting of garden wastes of Jambul ( $J$ ), Eucalyptus (E) and Ficus (F). Values are means of four replicates \pm standard errors

(Bars marked with the same capital letter indicate no significant deference for Jambul leaves, small letter is for Eucalyptus leaves, small letter between bracket's is for Ficus leaves) 
The results also showed significant differences between enzyme activities with time. It has been reported that the activity of xylanase increased and reached the maximum value after 30 days of composting (Shaheen, 2007; Khalil et al., 2012; 2013, 2014 a) and then decreased. However, Goyal et al. (2005) found that the maximum activity of xylanase was recorded after 60 days of composting then decreased afterwards.

\section{CONCLUSIONS}

The obtained results indicated that the changes in microbial populations and enzymatic activities during composting of garden wastes could be used as suitable indicators to characterize the dynamic of composting process and compost maturity when combined with some physical and chemical parameters such as temperature and $\mathrm{C} / \mathrm{N}$ ratio. Composting, by using bioreactor technique can be a suitable method for converting garden wastes into compost that can be used as an organic fertilizer and soil conditioner. Thus, the obtained results recommend the use of the static composting system (bioreactor) for composting organic raw wastes.

The results also showed that the quality and maturity of generated compost depend mostly on the type of raw organic materials used in the production processes. Different organic wastes will give rise to different quality of the final produced compost, with different characteristics and different potential markets.

\section{REFERENCES}

Abdullah, N. and N.L.Chin. 2010. Simplex-centroid mixture formulation for optimized composting of kitchen waste. Bioresource Technol. 101(21): 8205-8210.

Adhikari, B.K., S.Barrington, J. Martinez, and S. King. 2008. Characterization of food waste and bulking agents for composting. Waste Manage. 28: 795-804.

Adhikari, B.K., S.Barrington, J.Martinez and S. King. 2009. Effectiveness of three bulking agents for food waste composting. Waste manage. 29(1): 197-203.

Ahn, H.K., T.L. Richard and T.D. Glanville. 2008. Optimum moisture levels for biodegradation of mortality composting envelope materials. Waste Manage. 28: 14111416.

Albrecht, R., R.Joffre, R.Gros, J.Le Petit, G.Terrom and C. Périssol. 2008. Efficiency of near-infrared reflectance spectroscopy to asses and predict the stage of transformation of organic matter in the composting process. Bioresource Technol. 99: 448- 455.

Alkoaik, F.N., A.I. Khalil and T.Alqumajan. 2011. Performance evaluation of a static composting system using date palm residues, Middle East J. Sci. Res. 7(6): 972-983.
Auldry, C.P., H.A.Osumanu, N.M. Abd Majid, M.N.Hassan, J. Make and G.B. Michael. 2009. Chemical characteristics of compost and humic acid from sago waste. Am. J. of Applied Sci. 6 (11): 1880-1884.

Awasthi, M.K., A.K.Pandey, P.S. Bundela and J. Khan. 2015. Co-composting

of organic fraction of municipal solid waste mixed with different bulking waste: characterization of physicochemical parameters and microbial enzymatic dynamic. Bioresource Technol. 182: 200-207.

Bache, B.W. 1976. The measurement of cation exchange capacity of soils. J. Sci. Food and Agric. 27(3): 273-280.

Banegas, V., J.L.Moreno, J.I.Moreno, C.Garcia, G.Leon and T.Hernandez. 2007. Composting anaerobic and aerobic sewage sludges using two proportions of sawdust. Waste Manage. 27(10): 1317-1327.

Bass, L., T.E. Bilderback and M.A. Powell. 1992. Composting: A Guide to Managing Organic Yard Wastes. Raleigh, North Carolina: North Carolina Cooperative Extension Service. AG-467.

Beheary, M.S. 2000. Environment and Health Studies on Composting Case Study: Damietta Compost Plant, M.Sc. Thesis. Institute of Graduate Studies and Research, Alexandria University, Alexandria. Egypt.

Benito, M., A.Masaguer, A.Moliner, N. Arrigo and R.M. Palma. 2003. Chemical and microbiological parameters for the characterization of the stability and maturity of pruning waste compost. Biology Fertility Soils. 37(3): 184-189.

Bisaria, V.S. 1991). Bioprocessing of agro-residues to glucose and chemicals. In: Martin, A.M. (ed.). Bioconversion of Waste Materials to Industrial Products, Elsevier Applied Sci. London and New York.187-223.

Boldrin, A. 2009. Environmental Assessment of Garden Waste Management. Ph.D. Thesis, Department of Environmental Engineering Technical University of Denmark, Denmark.

Bustamante, M.A., R.Moral, C.Paredes, M.C. Vargas-García, F. Suárez-Estrella and J. Moreno. 2008. Evolution of the pathogen content during co-composting of winery and distillery wastes. Bioresource Technol. 99(15): 72997306.

Cabañas-Vargas, D.D., M.A.Sánchez-Monedero, S.T.Urpilainen, A. Kamillaki and E.I. Stentiford. 2005. Assessing the stability and maturity of compost at largescale plants. Ingeniería. 9(2): 25-30.

Cabrera, M.L., D.E. Kissel and M.F. Vigil. 2005. Nitrogen mineralization from organic residues: Research opportunities. J. Environ. Qual. 34(1): 75-79.

Chang, Y. and H.J. Hudson. 1967. The fungi of wheat straw compost. I. Ecological studies. Translations of British Mycological Soc. 50: 64.

Chukwujindu, M.A.I., A.C.Egun, F.N. Emuh and N.O. Isirimah. 2006. Compost maturity evaluation and its significance to agriculture. Pakistan J. of Biol. Sci. 9(15): $125-131$. 
Diaz, L.F., G.M.Savage, L.L. Eggebert and C.G. Golueke. 1993. Composting and Recycling Municipal Solid Waste. London: Lewis Publishers.

Elango, D., N.Thinakaran, P.Panneerselvam and S.Sivanesan. 2008. Thermophilic composting of municipal solid waste. Applied Energy. 86: 663-668.

Fang, M., M.H. Wong and J.W.C. Wong. 2001. Digestion activity of thermophilic bacteria isolated from ashamended sewage sludge compost. Water Air Soil Pollut. $126(1-2): 1-12$

Faure, D. and A.M. Deschamps.1990. Physico-chemical and microbiological aspects in composting of grape pulps. Biological Wastes. 34: 251-258.

Fogarty, A.M. and O.H. Tuovinen. 1991. Microbiological degradation of pesticides in yard waste composting. Microbiological Review. 55(2): 225.

Fujio, Y. and S.Kume. 1991. Isolation and characterization of thermophilic bacteria from sewage sludge compost. $J$. Fermentation Bioengineering. 72: 334-337.

Fusawat, P. and N. Rakariyatham. 2014. Potential of cellulase and xylanase production by fungal strains using corn husks as substrate. Khon Kaen University Res. J. 19: 229234.

Gajalakshmi, S. and S.A. Abbasi. 2008. Solid waste management by composting: State of the art. Critical Reviews Environ. Sci. and Technol. 38(5): 311-400.

Gotaas, H.B. 1956. Composting Sanitary Disposal and Reclamation of Organic Wastes. World Health Organization Monograph series. 31. Geneva.

Goyal, S., S.K. Dhull and K.K. Kapoor. 2005. Chemical and biological changes during composting of different organic wastes and assessment of compost maturity. Bioresource Technol. 96(14): 1584-1591.

Gümez-Brandün, M., C. Lazcano and J. Domínguez. 2008. The evaluation of stability and maturity during the composting of cattle manure. Chemosphere. 70: 436-444.

Guo, X., J. Gu, H.Gao, Q.Qin, Z.Chen, L.Shao, L.Chen, H.Li, W.Zhang, S.Chen and J. Liu. 2012. Effects of cu on metabolisms and enzyme activities of microbial communities in the process of composting. Bioresource Technol. 108: 140-148.

Hassen, A., K.Belguith, N.Jedidi, A.Cherif, M.Cherif and A. Boudabous. 2001. Microbial characterization during composting of municipal solid waste. Bioresource Technol. 80: 217-225.

Hassen, A., N.Jedidi, M.Cherif, A. M'hiri, A.Boudabous and O. Van Cleemput. 1998. Mineralization of nitrogen in a clayey loamy soil amended with organic waste residues enriched with $\mathrm{Zn}, \mathrm{Cu}$ and $\mathrm{Cd}$. Bioresource Technol. 64: 39-45.

Ja'afaru, M.I. 2013. Screening of fungi isolated from environmental samples for xylanase and cellulase production. ISRN Microbiology. 1-7. Article ID 283423.

Jimenez, E.I. and V.P. Garcia. 1989. Evaluation of city refuse compost maturity: a review. Biological Wastes. 27: 55.
Jindo, K., K.Suto, K.Matsumoto, C.García, T.Sonoki and M. A. Sánchez-Monedero. 2012. Chemical and biochemical characterisation of biocharblended composts prepared from poultry manure. Bioresource Technol. 110: 396-404.

Jusoh, M. L., L. A.Manaf and P. A. Latif. 2013. Composting of rice straw with Effective Microorganism (EM) and its influence on compost quality. Iranian J. of Environmental Health Sci. \& Engineering. 10: 10-17.

Kalamdhad, A.S. and A.A. Kazmi. 2009. Effects of turning frequency on compost stability and some chemical characteristics in a rotary drum composter. Chemosphere. 74(10): 1327-1334.

Kalamdhad, A.S., Y.K.Singh, M.Ali, M.Khwairakpam and A.A. Kazmi. 2009. Rotary drum composting of vegetable waste and tree leaves. Bioresource Technol. 100(24): 6442-6450.

Kayikçioğlu, H.H. and N. Okur. 2011. Evolution of enzyme activities during composting of tobacco waste. Waste Manage. and Res. 29(11): 1124-1133.

Khalib, S. N. B., I.A. Zakarya and T. N. T. Izhar. 2018. Composting of Garden Waste using Indigenous Microorganisms (IMO) as Organic Additive. International J. of Integrated Engineering. 140-145.

Khalil, A.I. 1996. Composting and the Utilization of Organic Wastes: An Environmental Study. Ph.D. Thesis, Institute of Graduate Studies and Research, Alexandria University, Alexandria, Egypt.

Khalil, A.I., M.S. Beheary and E.M. Salem. 1999. Changes in microbial populations and their enzymatic activities during the composting of municipal solid wastes: a comparative study. International Conference on Environmental Management, Health and Sustainable Development. Alexandria, Egypt.

Khalil, A.I., M.S. Beheary and E.M. Salem. 2001. Monitoring of microbial populations and their cellulolytic activities during the composting of municipal solid wastes. World Journal of Microbiology and Biotechnology. 17: 155.

Khalil, A.I., M.S.Hassouna, H.M.A. El-Ashqar and M. Fawzi. 2011. Changes in physical, chemical and microbial parameters during the composting of municipal sewage sludge. World J. Microbiol. and Biotechnol. 27: 23592369.

Khalil, A.I., A.R. Bin Ali and M.M. Yaqub. 2012. Microbial populations and enzymatic activities as parameters for characterization of the composting process. Alexandria Sci. Exchange J. 33(4): 314-325.

Khalil, A.I., M.S.Hassouna, M.M. Shaheen and M.A. Abou Bakr. 2013. Evaluation of the composting process through the changes in physical, chemical, microbial and enzymatic parameters. Asian J. of Microbiology, Biotechnol. Environ. Sci. 15(1): 25-42.

Khalil, A.I., M.S.Hassouna, M.M.Shaheen, M.A.L.Abou Bakr and A.M.A. Mashaly. 2014a. Monitoring of physical, chemical, microbial and enzymatic parameters during composting of municipal solid wastes: a comparative study. J. of Pure Applied Microbiol. 8(1): 211-224. 
Khalil, A.I., F.N.Alkoaik, M.A.Al-Mahasneh, R.B. Fulleros and A.M. El-Waziry. 2014b. Physical, chemical and microbial changes during composting of Conocarpus erectus residues. J. of Pure Applied Microbiol. 8(2):611622.

Khater, G. 2015. Some physical and chemical properties of compost. Inter J. Waste Resources. 5: 172.

Kirkpatrick, L.A. and B.C. Feeney. 2013. A simple guide to IBM SPSS statistics for version 20.0. Student ed. Belmont, Calif.: Wadsworth, Cengage Learning.

Kutsanedzie, F., G.N.K. Rockson and S. Achio. 2012. Comparison of compost maturity, microbial survival and health hazards in two composting systems. Journal of Microbiology, Biotechnol. Food Sci. 2: 175-193.

Lin, C. 2008. A negative-pressure aeration system for composting food wastes. Bioresource Technol. 99(16): 7651-7656.

Liu, D., R. Zhang, H.Wu, D.Xu, Z.Tang and G. Yu. 2011. Changes in biochemical and microbiological parameters during the period of rapid composting of dairy manure with rice chaff. Bioresource Technol. 102(19): 9040-9049.

Lu, A.L., M.Kumar, J.C. Tsai and J.G. Lin. 2008. High-rate composting of barley dregs with sewage sludge in a pilot scale bioreactor. Bioresource Technol. 99: 2210-2217.

Madan, S., A.Bhatia, A.Rajpal, and A.A. Kazmi. 2012. Maturity assessment of rotary drum and windrow composts in terms of germination index and enzymatic activities. Inter. J. Applied Sci. Engineer. Res. 1: 415-427.

Massiani, C. and M. Domeizel. 1996. Quality of compost organic matter stabilization and trace metal contamination. In: De M.Bertoldi, P.Sequi, B. Lemmes and T. Papi. (eds.). The Sciences of Composting, Blackie Academic and Professional, Glasgow. UK. 185-194.

Michel, F.C. and C.A. Reddy. 1998. Effect of oxygenation level on yard trimming composting rate, odor production and compost quality in bench-scale reactors. Compost Sci. Utilization. 6 (4): 6-14.

Miller, G.L. 1959. Use of dinitrosalicylic acid reagent for determination of reducing sugar. Anal. Chem. 31(3): 426428.

Miller, F.C. 1992. Biodegradation of solid wastes by composting. In: Martin, A.M. (ed.). Biological Degradation of Wastes. Elsevier Applied Science Publishers, London. 1-30.

Moldes, A., Y. Cendon and M.T. Barral. 2007. Evaluation of municipal solid waste compost as a plant growing media component, by applying mixture design. Bioresource Technol. 98 (16): 3069-3075.

Mondini, C., F. Fornasier and T. Sinicco. 2004. Enzymatic activity as a parameter for the characterization of the composting process. Soil Biology Biochem. 36 (10): 15871594.

Nakasaki, K., M. Shoda and H. Kubota. 1985. Effect of temperature on composting of sewage sludge. Applied Environ. Microbiol. 50: 1526-1530.
Nakasaki, K., A.Watanabe, M. Kitano and H. Kubota. 1992. Effect of seeding on thermophilic composting of refuse. $J$. Environ. Qual. 21: 715-719.

Nazim, S. G. 2019. Increasing Sustainability of Growing Media Constituents and Stand-Alone Substrates in Soilless Culture Systems. Agronomy

Pan, I. and S.K. Sen. 2013. Microbial and physic-chemical analysis of composting process of wheat straw. Indian J. Biotechnol. 12: 120-128.

Paredes, C., M.P.Bernal, J. Cegarra and A.Roig. 2002. Biodegradation of olive mill waste water sludge by its cocomposting with agricultural wastes. Bioresource Technol. 85: $1-8$.

Pérez-Murcia, M.D., J. Moreno-Caselles, R.Moral, A.PérezEspinosa, C. Paredes and B. Rufete. 2005. Use of composted sewage sludge as horticultural growth media: effects on germination and trace element extraction. Communications Soil Sci. Plant Anal. 36: 571-582.

Petric, I. and V. Selimbašiæ. 2008. Composting of poultry manure and wheat straw in a closed reactor: optimum mixture ratio and evolution of parameters. Biodegradation. 19: 53-63.

Raut, M.P., S.P.M. Prince William, J.K. Bhattacharyya, T. Chakrabarti and S.Devotta. 2008. Microbial dynamics and enzyme activities during rapid composting of municipal solid waste a compost maturity analysis perspective. Bioresource Technol. 99(14): 6512-6519.

Reddy, K.S., N.Kumar, A.K.Sharma, C.L. Acharya and R.C. Dalal. 2005. Biophysical and sociological impacts of farmyard manure and its potential role in meeting crop nutrient needs: a farmers' survey in Madhya Pradesh, India. Australian J. Experiment. Agric. 45 (4): 357-367.

Saharinen, M.H. 1998. Evaluation of changes in CEC during composting. Compost Sci. Utilization. 6(4): 29-37.

Said-Pullicino, D., F.G. Erriquens and G. Gicliotti. 2007. Changes in the chemical characteristics of waterextractable organic matter during composting and their influence on compost stability and maturity. Bioresource Technol. 98: 1822-1831.

Saludes, R.B., K.Iwabuchi, F.Miyatake, Y. Abe and Y.Honda. 2008. Characterization of dairy cattle manure wallboard paper compost mixture. Bioresource Technol. 99(15): 7285-7290.

Shaheen, M.M. 2007. Environmental Studies on Composting of Municipal Solid Wastes. M.Sc. Thesis. Institute of Graduate Studies and Research University of Alexandria, Alexandria, Egypt.

Shilev, S., M.Naydenov, V. Vancheva and A. Aladjadjiyan. 2006. Composting of Food and Agricultural Wastes. Department of Microbiology and Environmental Biotechnologies, Agricultural University-Plovdiv, Plovdiv, Bulgaria.

Smårs, S., L.Gustafsson, B.Beck-Friis and H. Jönsson. 2002. Improvement of the composting time for household waste during an initial low $\mathrm{pH}$ phase by mesophilic temperature control. Bioresource Technol. 84(3): 237-241. 
Suvendu, D., T. J.Seung, D.Subhasis and J. K. Pil . 2017. Composted Cattle Manure Increases Microbial Activity and Soil Fertility More Than Composted Swine Manure in a Submerged Rice Paddy. Frontiers microbiol. 8:1-10.

Vargas-García, M.C., F.Suárez-Estrella, M.J. López and J.Moreno. 2010. Microbial population dynamics and enzyme activities in composting processes with different starting materials. Waste Manage. 30 (5): 771-778.

Villaseñor, J., L.Rodríguez and F.J. Fernández. 2011. Composting of domestic sewage sludge with natural zeolites in a rotary drum reactor. Bioresource Technol. 102: 1447-1454.

Wang, Q., R.Li, H.Caia, M.K.Awasthi, Z.Zhang, J.J.Wang, A. Ali and M.Amanullah. 2016. Improving pig manure composting efficiency employing Ca-bentonite. Ecological Engineer. 87: 157-161.

Weber, J., A.Karczewska, J.Drozd, M.Licznar, S.Licznar, E. Jamroz and A. Kocowicz 2007. Agricultural and ecological aspects of a sandy soil as affected by the application of municipal solid waste composts. Soil Biology Biochem. 39: 1294-1302.
WHO. 1978. Methods of Analysis of Sewage Sludge, Solid Wastes and Compost. WHO International References Center for Wastes Disposal. CH-8600, Bübendorf, Switzerland.

Yadav, A. and V.K. Garg. 2009. Feasibility of nutrient recovery from industrial sludge by vermicomposting technology. J. Hazardous Materials. 168: 262-268.

Yadav, K.D., V.Tare and M.M. Ahammed. 2011. Vermicomposting of source-separated human faeces by Eisenia fetida: Effect of stocking density on feed consumption rate, growth characteristics and vermicompost production. Waste Manage. 31: 1162-1168.

Zakarya, I., S.Khalib, T. Tengku Izhar and S. Yusuf. 2015. Engineering Res. Technol. 4(8): 181-184.

Zhou, Y., A.Selvam and J.W. Wong. 2014. Evaluation of humic substances

during co-composting of food waste, sawdust and Chinese medicinal herbal residues. Bioresource Technol. 168: 229234.

Zhu, N. 2007. Effect of low initial $\mathrm{C} / \mathrm{N}$ ratio on aerobic composting of swine manure with rice straw. Bioresource Technol. 98: 9-13.

Zmora-Nahum, S., O.Markovitcha, J. Tarchitzky and Y.Chen. 2005. Dissolved organic carbon (DOC) as a parameter of compost maturity. Soil Biology Biochem. 37: 2109-2116. 


\section{الملخص العربي}

متابعة التغيرات في بعض الصفات الفيزيائية، الكيميائية، الميكروبية و الإنزيمية خلال عملية صناعة السماد البلاي لثلاثة توليفات من مخلفات الددائق

أحمد خليل، محمد نبيل، هالة بدري

لكل من البكتيريا و الفطريات المحبة لارجة الحرارة المتوسطة فحدث لهم إنخفاض مع تقدم زمن التخمر بينما البكتيريا و

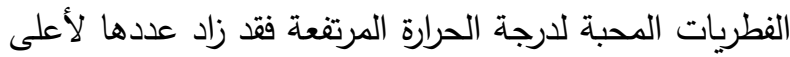
قيمة بعد عشرة أيام من بداية عملية الكمبوست و من ثم قلت تزادت قيمته لأعلى قيمة لله بعد خمسة أيام

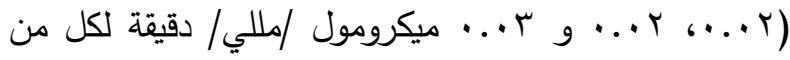
مخلفات أشجار الزامبوزيا، الكافور و الفيكيس بالترتيب ) ثم إنخفض تدريجيا، بينما كانت أعلى قيمة لنشاط إنزيم كاربوكسي ميثيل سيليولايز (ء... ميكرومول/ميللي/دقيقة لمخلفات الأوراق للثلاثة أشجار موضع الدراسة و ذلك بعد خمسة أيام من بداية التخمر ثم إنخفضت القيم تدريجيا بنهاية

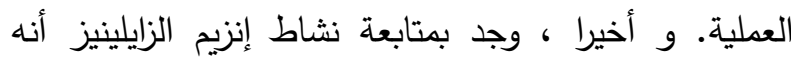

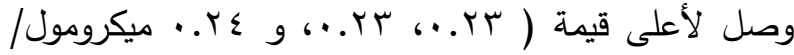

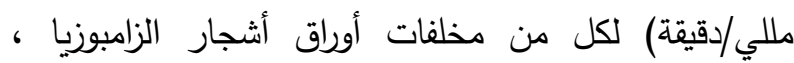
الكافور و الفيكس بالترتيب و ذلك بعد عشرة أيام من بداية التخمر ثم أخذ بالإنخفاض بنهاية العملية.
تهدف الدراسة الحالية لتقيم عملية صناعة السماد العضوي (الكمبوست) لثلاثة توليفات من مخلفات الحدائق عن طريق متابعة التغير في بعض الصفات الفيزيائية، الكيميائية، الميكروبية والإنزيمية خلال عملية صناعة صنيز الكمبوست والتي أجريت بإستخدام المفاعل الحيوي. المخلفات المستخدمة هي قصاصات العشب والأوراق المتساقطة لأشجار الزامبوزيا، قصاصات العشب والأوراق المتساقطة لأشجار الكافور وأخيرا قصاصات العشب والأوراق المتساقطة لأشجار الفيكس. النتائج الخاصة بمتابعة التغيرات الفيزيائية تفيد بزيادة درجة الحرارة لتصل لأعلى قيمة لها بعد عشرة أيام من بداية عملية الكمبوست ثم تقل تدريجيا بنهاية العملية، كذلك وجود تغير واضح في اللون والرائحة. أما عن الصفات الكيميائية فقد شملت كل من كمية الرماد، نسبة النيتروجين الكلي و السعة التبادلية الكاتيونية فقد زادت قيمهم معنويا

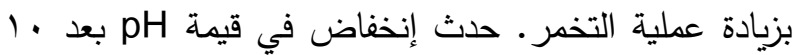
أيام ثم بدأ في الزيادة تدريجيا حتى وصل لأعلى قيمة له لهاده بنهاية عملية الكمبوست. أما التوصيل الكهربي فقد زاد خلال العشرة أيام الأولى ثم انخفض تدريجيا بنهاية التخمر • بالنسبة 